\title{
X-ray Diffraction Analysis of $\boldsymbol{\gamma}_{2}(\mathrm{Sn}-\mathrm{Hg})$ Phase in High Copper Amalgams of Varying Mercury Content
}

\author{
MANOHAR L. MALHOTRA* and KAMAL ASGAR \\ School of Dentistry, The University of Michigan, Ann Arbor, Michigan 48109
}

\begin{abstract}
Microstructures of high copper commercial amal. gams containing varying amounts of mercury, ranging from $20 \%$ above to $25 \%$ below recommended values, were primarily investigated by $x$ ray diffraction. Mechanisms relating to the absence or presence of $\gamma_{2}(\mathrm{Sn}-\mathrm{Hg}$ ) phase in these amalgams were discussed in relation to the presence of copper and tin elements in their original alloys. The optimum mercury concentration in some amalgams was determined in order to keep them free of the $\gamma_{2}(\mathrm{Sn}-\mathrm{Hg})$ phase.
\end{abstract}

J Dent Res 60(2):149-153, February 1981

\section{Introduction.}

Recently, some high copper amalgams have been added to the certified list of the American Dental Association. ${ }^{1-3}$ The promising laboratory and clinical test results of these amalgams indicate a great potential for use in future restorations. ${ }^{4-7}$ The superior physical properties obtained from most high copper amalgams resulted from the absence of $\gamma_{2}(\mathrm{Sn}-\mathrm{Hg})$ phase in their microstructure. However, the absence of $\gamma_{2}$ phase in some high copper amalgams was only true when the recommended mercury concentration was used. Jensen ${ }^{8}$ has shown that Tytin amalgam containing 50\% and $60 \%$ mercury showed the presence of $\gamma_{2}$ phase. Mahler and Adey ${ }^{9}$ found that in three high copper amalgams certain changes occurred

Received for publication January 2, 1980 Accepted for publication March 6, 1980

This investigation was presented at the Annual General Session of the International Association for Dental Research, Washington, D.C. (March, 1978).

*Present Address: Julius Aderer, Inc., 21-25 44th Avenue, Long Island City, NY 11101

This research was completely supported by a postdoctoral award to one of the authors (Dr. M. L. Malhotra) from the National Institute of Dental Research, National Institutes of Health, Bethesda, MD 20205 under Research Grant No. 4 F32 DE-05029-03. when the mercury content reached a specific range. These changes were: a relatively large increase in creep, an increase in susceptibility to etching at the $\gamma_{1}(\mathrm{Ag}-\mathrm{Hg})$ grain boundaries, and an increase in tin content in the $\gamma_{1}$ phase.

The above results initiated the present study to investigate microstructure in some high copper amalgams (made from commercial alloys) containing different mercury concentrations in their set amalgams. The mercury concentrations were varied from $20 \%$ above to $25 \%$ below their recommended values. Commercial dental amalgam alloys selected were Tytin, Sybraloy, Indiloy, Dispersalloy, Optaloy II, and Micro II.

\section{Materials and methods.}

Table 1 shows the brand of the selected alloys, their manufacturers, recommended mercury-to-alloy ratios, mechanical amalgamators used, trituration times, and the weight of the pestles used in their specified capsules. Table 2 shows their approximate chemical composition and the shape of the original alloy particles. Amalgams of varying mercury content (Table 3 ) were prepared and allowed to set at $37^{\circ} \mathrm{C}$ for two wk prior to study. Amalgams were crushed to smallsized particles for $x$-ray diffraction measurements. The $x$-ray machine used was a Phillip's (XRG-3000) x-ray generator with copper $\mathrm{K}_{\alpha}$ radiation $(\lambda=1.54 \AA)$ and $\mathrm{a}$ nickel filter. In order to obtain accurate values for $2 \theta^{\circ}$, the diffractometer scanning speed was adjusted to $1^{\circ}$ per min. The $x$-ray signal, after being amplified, was recorded on a chart recorder and calibrated for oneinch equivalent to $1^{\circ}$. The $2 \theta^{\circ}$ values obtained from diffraction peaks were converted into d-spacings using standard conversion tables. The observed d-values of all the diffraction peaks in conjunction with the ASTM tables were used to identify the presence of metallic phases containing crystallites of different orientations. 
TABLE 1

\begin{tabular}{|c|c|c|c|c|c|c|}
\hline Dental Alloy & Manufacturer & Batch No. & $\begin{array}{l}\text { Recommended } \\
\mathrm{Hg}(\%)\end{array}$ & $\begin{array}{l}\text { Amalgamator } \\
\text { Used }\end{array}$ & $\begin{array}{l}\text { Trituration } \\
\text { Time (sec) }\end{array}$ & $\begin{array}{l}\text { Weight } \\
\text { of } \\
\text { Pestle } \\
\text { (gm) }\end{array}$ \\
\hline $\begin{array}{l}\text { Tytin } \\
\text { (predispensed) }\end{array}$ & $\begin{array}{l}\text { S. S. White } \\
\text { Philadelphia, } \\
\text { PA }\end{array}$ & 17511 & 43.0 & Capmaster & 6 & -- \\
\hline $\begin{array}{l}\text { Sybraloy } \\
\text { (predispensed) }\end{array}$ & $\begin{array}{l}\text { Kerr Mfg. } \\
\text { Company } \\
\text { Romulus, MI }\end{array}$ & 1009751277 & 46.0 & $\begin{array}{l}\text { Caulk Vari-Mix } \\
\text { II (M-2 setting) }\end{array}$ & 10 & 0.206 \\
\hline $\begin{array}{l}\text { Indiloy } \\
\text { (powder) }\end{array}$ & $\begin{array}{l}\text { Shofu Dental } \\
\text { Corp. } \\
\text { Menlo Park, } \\
\text { CA }\end{array}$ & 307602 & 46.0 & Capmaster & 15 & -- \\
\hline $\begin{array}{l}\text { Dispersalloy } \\
\text { (predispensed) }\end{array}$ & $\begin{array}{l}\text { Johnson \& } \\
\text { Johnson } \\
\text { East Windsor, } \\
\text { NJ }\end{array}$ & $\underset{8137-002841}{\text { HRI }}$ & 50.0 & $\begin{array}{l}\text { Caulk Vari-Mix } \\
\text { II (M-2 setting) }\end{array}$ & 12 & 0.689 \\
\hline $\begin{array}{l}\text { Optaloy II } \\
\text { (pellets) }\end{array}$ & $\begin{array}{l}\text { L. D. Caulk } \\
\text { Company } \\
\text { Milford, DE }\end{array}$ & $1264-601624$ & 54.0 & $\begin{array}{l}\text { Caulk Vari-Mix } \\
\text { II (M-2 setting) }\end{array}$ & 14 & 0.594 \\
\hline $\begin{array}{l}\text { Micro II } \\
\text { (pellets) }\end{array}$ & $\begin{array}{l}\text { L. D. Caulk } \\
\text { Company } \\
\text { Milford, DE }\end{array}$ & $1264-601452$ & 54.0 & $\begin{array}{l}\text { Caulk Vari-Mix } \\
\text { II (M-2 setting) }\end{array}$ & 14 & 0.594 \\
\hline
\end{tabular}

TABLE 2

APPROXIMATE CHEMICAL COMPOSITION (\%)

\begin{tabular}{lclrrrr}
\hline \hline Types & Alloys & Ag & Sn & Cu & In & Shape \\
\hline \multirow{3}{*}{ Uni-Comp. } & Tytin & 60 & 27 & 13 & - & Sphere \\
& Sybraloy & 40 & 30 & 30 & - & Sphere \\
& Indiloy & 60 & 22 & 13 & 5 & Sphere \\
& Dispersalloy & 72 & - & 28 & - & Sphere \\
Ad-Mix & & 69 & 27 & 4 & - & Irregular \\
& Optaloy II & 66 & 9 & 25 & - & Sphere \\
& & 76 & 23 & 1 & - & Irregular \\
& Micro II & 65 & 9 & 26 & - & Sphere \\
& & 72 & 26 & 2 & - & Irregular \\
\hline
\end{tabular}

Results.

The Fig. shows partial $x$-ray diffraction patterns over the important range of $2 \theta^{\circ}$ values to detect $\gamma_{2}$ phase peaks in amalgams made from recommended mercury content. The identification of these diffraction patterns has already been discussed. ${ }^{5}$ For amalgams containing varying amounts of mercury, the absence or presence of $\gamma_{2}$ phase in their microstructure is given in Table 3.

\section{Discussion.}

Before dealing with the observed x-ray diffraction patterns, the following mechanisms are described in order to understand the absence or presence of $\gamma_{2}$ phase in these amalgams.

Mechanisms for the absence or presence of $\gamma_{2}$ phase. - Amalgams made from unicomposition alloys. It is well known that the original alloy particles contain mostly $\mathrm{Ag}_{3} \mathrm{Sn}$ 
TABLE 3

MERCURY CONCENTRATIONS IN AMALGAMS

\begin{tabular}{|c|c|c|c|c|c|c|c|c|c|c|}
\hline Amalgam & $\begin{array}{c}25 \% \\
\text { Below } \\
\text { Recom. } \\
(\%)\end{array}$ & $\begin{array}{c}20 \% \\
\text { Below } \\
\text { Recom. } \\
(\%)\end{array}$ & $\begin{array}{c}15 \% \\
\text { Below } \\
\text { Recom. } \\
(\%)\end{array}$ & $\begin{array}{c}10 \% \\
\text { Below } \\
\text { Recom. } \\
(\%)\end{array}$ & $\begin{array}{c}5 \% \\
\text { Below } \\
\text { Recom. } \\
(\%)\end{array}$ & $\begin{array}{c}\mathrm{Hg} \text { As } \\
\text { Recom. } \\
(\%)\end{array}$ & $\begin{array}{c}5 \% \\
\text { Above } \\
\text { Recom. } \\
(\%)\end{array}$ & $\begin{array}{c}10 \% \\
\text { Above } \\
\text { Recom. } \\
(\%)\end{array}$ & $\begin{array}{c}15 \% \\
\text { Above } \\
\text { Recom. } \\
(\%)\end{array}$ & $\begin{array}{c}20 \% \\
\text { Above } \\
\text { Recom. } \\
(\%)\end{array}$ \\
\hline Tytin & 32.2 & 34.4 & 36.5 & 38.7 & 40.8 & 43.0 & 45.2 & 47.3 & 49.5 & 51.6 \\
\hline Sybraloy & 34.5 & 36.8 & 39.1 & 41.4 & 43.7 & 46.0 & 48.3 & 50.6 & 52.9 & 55.2 \\
\hline Indiloy & 34.5 & 36.8 & 39.1 & 41.4 & 43.7 & 46.0 & 48.3 & 50.6 & 52.9 & 55.2 \\
\hline Dispersalloy & 37.5 & 40.0 & 42.5 & 45.0 & 47.5 & 50.0 & 52.5 & 55.0 & 57.5 & 60.0 \\
\hline Optaloy II & 40.5 & 43.2 & 45.9 & 48.6 & 51.3 & 54.0 & 56.7 & 59.4 & 62.1 & 64.8 \\
\hline Micro II & 40.5 & 43.2 & 45.9 & 48.6 & 51.3 & 54.0 & 56.7 & 59.4 & 62.1 & 64.8 \\
\hline
\end{tabular}

Underline indicates the presence of $\gamma_{2}$ phase.

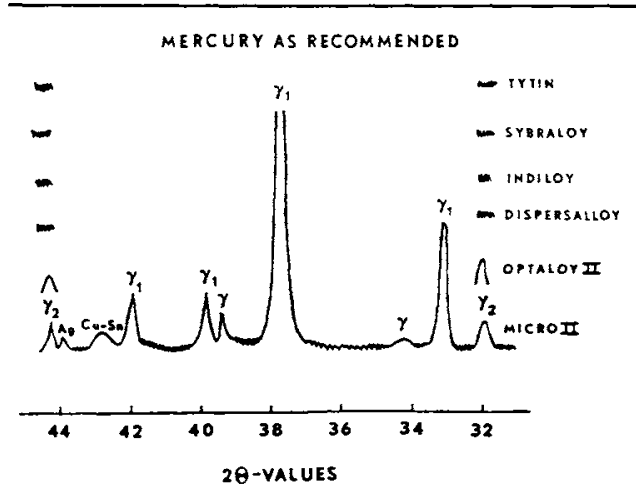

Fig. - Partial x-ray diffraction patterns over the important range of $2 \theta^{\circ}$ values, showing the absence or presence of $\gamma_{2}$ phase in amalgams made from recommended mercury content.

and $\mathrm{Cu}_{3} \mathrm{Sn}$ phases. Also, the reaction of these alloy particles with mercury is limited to the outer surface layers of the particles, while most of the inner part of the particles remains unreacted. To explain this reaction, one of two possible mechanisms is probably taking place: 1) Initially, $\gamma_{1}(\mathrm{Ag}-\mathrm{Hg})$ and $\gamma_{2}$ $(\mathrm{Sn}-\mathrm{Hg})$ phases are formed. Since the $\gamma_{2}$ phase is unstable, tin from this phase combines with $\mathrm{Cu}_{3} \mathrm{Sn}$ to form $\mathrm{Cu}_{6} \mathrm{Sn}_{5}$ as observed in $\mathrm{x}$-ray diffraction. Released mercury from $\gamma_{2}$ phase again reacts with original $\gamma$ particles in the same fashion. Hence, the set amalgam becomes free from $\gamma_{2}$ phase, and the major amalgam products are $\gamma_{1}, \mathrm{Cu}_{6} \mathrm{Sn}_{5}$, and $\gamma$ (unreacted) particles; or 2 ) as mercury reacts with $\mathrm{Ag}_{3} \mathrm{Sn}$ of the original particle to form $\gamma_{1}$, the released tin from $\mathrm{Ag}_{3} \mathrm{Sn}$ reacts with $\mathrm{Cu}_{3} \mathrm{Sn}$ and forms $\mathrm{Cu}_{6} \mathrm{Sn}_{5}$ phase. In this manner no $\gamma_{2}$ is formed, and the final product is the same $\gamma_{1}, \mathrm{Cu}_{6} \mathrm{Sn}_{5}$, and the $\gamma$ (unreacted) particle. Thus, the absence of $\gamma_{2}$ phase in Tytin, Sybraloy, and Indiloy amalgams when made from their recommended mercury values can be explained with one of these two mechanisms.

Amalgams made from ad-mixed composition alloys. Dispersalloy contains a blend mixture of lathe-cut $\mathrm{Ag}_{3} \mathrm{Sn}$ particles, with spherical $\mathrm{Ag}-\mathrm{Cu}$ eutectic particles. Initially, mercury reacts with $\mathrm{Ag}_{3} \mathrm{Sn}$ and $\mathrm{Ag}-\mathrm{Cu}$ eutectic separately. The $\gamma_{1}(\mathrm{Ag}-\mathrm{Hg})$ and $\gamma_{2}$ $(\mathrm{Sn}-\mathrm{Hg})$ phases are produced from $\gamma\left(\mathrm{Ag}_{3} \mathrm{Sn}\right)$ particle reaction, and small amounts of the additional $\gamma_{1}$ phase are also produced from silver of $\mathrm{Ag}$-Cu eutectic particles. Because the $\gamma_{2}$ phase is unstable, the tin from this phase combines with copper of $\mathrm{Ag}-\mathrm{Cu}$ eutectic and forms $\mathrm{Cu}_{6} \mathrm{Sn}_{5}$ phase, as observed in $x$-ray diffraction. The released mercury from $\gamma_{2}$ phase reacts with silver of $\mathrm{Ag}-\mathrm{Cu}$ eutectic, forming some additional $\gamma_{1}$ phase. Hence, the set Dispersalloy amalgam becomes free from the $\gamma_{2}$ phase, and the major amalgamated products are $\gamma_{1}, \mathrm{Ag}-\mathrm{Cu}$ eutectic surrounded by $\mathrm{Cu}_{6} \mathrm{Sn}_{5}$, and $\gamma$ (unreacted particles). This mechanism explains the absence of $\gamma_{2}$ phase in Dispersalloy amalgam. The presence of $28 \%$ copper in $\mathrm{Ag}-\mathrm{Cu}$ eutectic particle of Dispersalloy was sufficient to completely eliminate $\gamma_{2}$ phase in its amalgam for all mercury values used in this investigation.

However, Optaloy II and Micro II alloys contain about $9 \%$ tin in their Ag-Cu eutectic (Table 2). The presence of $9 \%$ tin in $\mathrm{Ag}-\mathrm{Cu}$ eutectic is held responsible for the appearance of $\gamma_{2}$ phase in the amalgams, as explained in the following hypothesis. The reaction of 
mercury with these alloys produces $\gamma_{2}$ phase in two ways: 1) the reaction of mercury with tin from the surface layers of $\mathrm{Ag}_{3} \mathrm{Sn}$ $(\gamma)$ particles, and (2) the reaction of mercury with tin contained in the $\mathrm{Ag}-\mathrm{Cu}$ eutectic particles. In fact, the presence of $9 \%$ tin in $\mathrm{Ag}-\mathrm{Cu}$ eutectic produces some more $\gamma_{2}$ phase, and the copper in these alloys is not in sufficient quantities to be able to eliminate all of the $\gamma_{2}$ phase formed. This explained the presence of $\gamma_{2}$ phase in both Optaloy II and Micro II amalgams for all values of mercury ranging from $25 \%$ below to $20 \%$ above their recommended amounts.

The above mechanisms would be employed to explain the observed x-ray diffraction data from amalgams of varying mercury.

Amalgams containing mercury as recommended. - The Fig. shows a typical presentation of partial $x$-ray diffraction patterns from amalgams made from mercury, as recommended by their manufacturers. The analysis has shown (Table 3) that Tytin, Sybraloy, Indiloy, and Dispersalloy amalgams were free from $\gamma_{2}$ phase, while Optaloy II and Micro II amalgams contained $\gamma_{2}$ phase in their microstructure. The absence or presence of $\gamma_{2}$ phase in these amalgams has already been discussed.

Amalgams containing mercury above recommended levels. - Table 3 indicates that Indiloy amalgam containing mercury $5 \%$ or above the recommended value and Tytin amalgam containing mercury $15 \%$ or above the recommended value contained $\gamma_{2}$ phase in their microstructure. Since Tytin and Indiloy amalgams contained the same amount of copper in their original alloys (Table 2), the absence or presence of $\gamma_{2}$ phase in these amalgams would depend upon some optimum value of mercury concentration used in the reaction. Table 3 shows that Tytin amalgam made from $47.3 \%$ mercury (10\% above recommended value) was free from $\gamma_{2}$ phase, while Indiloy amalgam containing $48.3 \%$ mercury $(5 \%$ above recommended value) contained $\gamma_{2}$ phase. Approximately $48 \%$ mercury seemed to be the limit for these amalgams to be free from $\gamma_{2}$ phase. In practice, an amalgam made from recommended mercury is packed in the prepared tooth cavity, and the applied condensation force further reduces the mercury content in the bulk of the restoration. The mercury concentration of amalgam around the margins is known to be higher than the bulk; however, it is not any higher than 2 to 3 percent of the recommended values. ${ }^{10}$ For example, for Tytin the mercury content would not exceed $44-45 \%$, whereas for Indiloy it would reach $47-48 \%$. As shown, Tytin amalgam with $44-45 \%$ mercury is free from $\gamma_{2}$, whereas $47-48 \%$ mercury for Indiloy would start to produce some $\gamma_{2}$ phase.

Sybraloy and Dispersalloy amalgams were totally free from $\gamma_{2}$ phase with up to $20 \%$ higher mercury than that which is recommended. With such a high mercury concentration it is almost impossible to pack amalgam. Optaloy II and Micro II amalgams always contained $\gamma_{2}$ phase in their microstructure for all mercury values up to $20 \%$ above those recommended.

Amalgams containing mercury below recommended values. - Table 3 shows the absence or presence of $\gamma_{2}$ phase in amalgams containing mercury up to $25 \%$ below their recommended values. The metallurgical behavior of these amalgams was similar to amalgams made from recommended mercury. Optaloy II and Micro II amalgams contained some $\gamma_{2}$ phase even when triturated with mercury at $25 \%$ below those values recommended. However, the amalgams were very dry and practically unusable.

\section{Conclusions.}

1. All high copper amalgams are not completely free of the weak $\gamma_{2}$ phase. Absence of the $\gamma_{2}$ phase in high copper amalgams depends on the composition of the original alloy, as well as the final mercury content in set amalgam.

2. Certain hardened high copper dental amalgams with higher mercury contents than recommended have a greater chance of containing $\gamma_{2}$ phase than when they contained lower amounts of mercury.

3. Set Micro II and Optaloy II amalgams showed $\gamma_{2}$ phase even when they contained the recommended mercury content.

4. Indiloy amalgam is free from $\gamma_{2}$ phase at recommended mercury-to-alloy ratios, but will show $\gamma_{2}$ phase in its microstructure when the mercury-to-alloy ratio is increased to $5 \%$ above that which is recommended. However, from a practical view it is difficult 
to condense any spherical amalgam alloys when triturated with $5 \%$ higher mercury than that which is recommended.

5. Tytin amalgam is free of the $\gamma_{2}$ phase up to $10 \%$ above the recommended mercury-to-alloy ratios, and somewhere between 10 and $15 \%$ above the recommended ratios, the $\gamma_{2}$ phase appears.

6. X-ray diffraction patterns for Sybraloy and Dispersalloy do not show any $\gamma_{2}$ peaks, even when mercury-to-alloy ratios were increased $20 \%$ above their recommended values.

\section{REFERENCES}

1. Council on Dental Materials and Devices, American Dental Association: List of Certified Dental Materials and Devices Revised to Jan. 1, 1977, JADA 94:135, 1977.

2. Council on Dental Materials and Devices, American Dental Association: Supplement of the List of Certified Dental Materials and Devices, JADA 95:131, 1977.
3. Council on Dental Materials and Devices, American Dental Association: Certified Alloys for Dental Amalgam, JADA 96: $126,1978$.

4. MALHOTRA, M.L. and ASGAR, K.: Physical Properties of Dental Silver-Tin Amalgams with High and Low Copper Contents, JADA 96:444, 1978.

5. MALHOTRA, M.L. and ASGAR, K.: Microstructure of Dental Amalgams Containing High and Low Copper Contents, $J$ Dent Res 56:1481-1487, 1977.

6. MAREK M. and HOCHMAN, R.F.: Corrosion Properties of a Low Silver and High Copper Dental Amalgam, IADR Progr \& Abst 55: No. 282, 1976.

7. MOFFA, J.P. and JENKINS, W.A.: Two Year Clinical Evaluation of a Dispersed Phase and a Single Phase Amalgam, IADR Progr \& Abst 56: No. $114,1977$.

8. JENSEN, S.J.: Phase Content of a High Copper Dental Silver Amalgam, Scand J Dent Res $85: 297,1977$.

9. MAHLER, D.B. and ADEY, J.D.: Characteristics of a High Copper Amalgam, IADR Progr \& Abst 56: No. 145, 1977.

10. MAHLER, D.B.: Behavior of Three High-Cu Amalgams, J Biomed Mater Res 13:693, 1979.

\section{GORDON CONFERENCE ON "PERIODONTAL DISEASES"}

A Gordon Research Conference on "Periodontal Diseases" is scheduled to be held July 20-24, 1981, at Colby-Sawyer College, New London, New Hampshire. The conference is intended to promote discussions and exchange of the most recent advances on the various aspects of periodontal disease research. Sessions are being planned on Normal Structure and Pathogenesis, Microbial Etiology, Host Response Mechanisms, Connective Tissue Alterations, Fibroblast Function and Regulation, Bone Resorption, Wound Healing, and Application of Basic Information. Complete details of the conference will appear in the March 13, 1981, issue of Science. For information contact: Dr. A.S. Narayanan at the Department of Pathology, SM-30, University of Washington, Seattle, WA 98195 (Phone 206-543-6638). 